We should expect to find in the remaining less-arid parts the general occurrence of the old Afro-Australian flora, and this we do very conspicuously, for it still provides much of the most typical Australian plant life. We should expect a relative absence of specialized desert types because the conditions for their development came after the separation of Australia from areas with such types now, and this, of course, is true. Finally, we should expect to find a strong infiltration of Melanesian types, mostly tropical rain-forest plants, in the north and east wherever the rainfall is sufficient, and the presence of this kind of vegetation in the high rainfall areas of the north-east is familiar and conspicuous.

Hence the sequence of events outlined provides a reasonable explanation of the major features of the present Australian flora without recourse to former land connexions of any kind, except in so far, of course, as the present Torres Straits have almost certainly been dry land on occasion during the very recent geological past, that is to say, on the present hypothesis, since Australia reached New Guinea.

It will be clear now that two very important aspects of the circumstantial evidence mentioned earlier will be the palæontological and the palæoclimatic, and it may therefore be reiterated that according to my hypothesis I should expect the Angiosperm fossil record of much of Australia to show in sequence, first a fairly widespread flora predominantly of a temperate rain-forest kind; secondly, a contraction of this and a spread of an 'Afro-Australian' flora (such as is exemplified by acacias, Proteaceae, Restionaceae, Ericales and various Monocotyledons); thirdly, more widespread evidence of aridity accompanied or closely followed by a great increase in such plants as Casuarina and Eucalyptus, together with the apperance of some development of tropical rain-forest in the north-east and east; and fourthly, one or more short-term extensions of the more mesophytic kinds of vegetation during the pluvial stages of the Pleistocene.

There is not yet much to guide us in dating these successive phases, but there are one or two pointers. In the larger plant groups, particularly families, there is, with one particular exception to be mentioned, good agreement between the present floras of South Africa and Australia, and it seems clear from this that if the two regions have indeed drifted apart then the process must have begun after the general differentiation of the Angiosperms, that is to say, not earlier than the later Cretaceous or the earliest Tertiary. On the other hand, it may, so far as the plants are concerned, have started at almost any later time, the more recent the start the shorter, of course, being the duration of the movement. Again, whether drift has boen going on slowly for a long time or has taken place wholly within a comparatively short time, we do not know. At the nearer end of the time-scale the considerable size of the Melanesian element in the Australian flora to-day (together with the much smaller selection of Australian plants in New Guinea) suggests that an appreciable time has elapsed since these two became close enough together to populate one another, and this in turn may merit the speculation that their approximation was during or at the end of the Pliocene.

On one point the fossil record may be of special importance. The underlying affinity of the floras of South Africa and Australia has been stressed more than once and it should therefore be made plain that there are also puzzling differences between the two. This is notably the case with two of what are now characteristic Australian types, Casuarina and the Myrtaceae, especially, of course, Eucalyptus. Neither of these is prominent in Africa; the Myrtaceae are very poorly represented there even in the tropics, and Casuarina does not occur native at all. Yet both are well-developed and characteristic features of the Melanesian tropical flora. Several species of Eucalyptus itself occur there, one of which at least is generally regarded as among the least specialized. May it not be, then, that these two genera, doubtless among others, are not in fact Australian types in origin, despite their prominence there to-day, but among the most conspicuous examples of that filling of a partial vacuum, mentioned earlier, by appropriate stocks from Melanesia?

Finally, it must not be forgotten that the sequence of events outlined above presupposes the present latitudinal distribution of climate, which arises from the position of the poles, to have remained unchanged throughout. To have incorporated the possibility that there was at the same time polar movement would have complicated the picture too much, but it must always be remembered that if, as there seems reason to believe, there may have been some such contemporary changes in the positions of the poles, these could have had one of three effects. They could have intensified the climatic changes sug. gested; they could have reversed them; or they could even have prevented them. They could scarcely, however, have affected the movement of Australia in itself.

'Good, R., Nature, 179, 926 (1957).

2 Good, R., Austral. J. Sci., 20, 41 (1957).

\title{
OBITUARIES
}

\section{Dr. Emil Abel}

Dr. EmL ABex died in London on April 3 in his eighty-third year, after a short illness. $\mathrm{He}$ had studied in Vienna and then under Nernst. In 1905 he established himself as Privatdozent at the Technische Hochsehule in Vienna, and when a chair of physical chemistry was created he was appointed professor and head of the institute attached to the chair. He held this position until the Anschluss in 1938, when he was dismissed under the Nuremberg laws. With his family he found refuge in England; during the War, and for several years after, until his retirement, he was in charge of the research laboratory of the Ever Ready Co., Ltd.

Though he contributed to many branches of physical chemistry, his main interest was chemical kinetics. His early work was devoted to homogeneous catalysis, and he showed in a series of brilliant papers that the role of the catalyst is the creation of additional reaction paths from the reactants to the products. $\mathrm{H}_{\Theta}$ used to insist 
firmly that "it is reactions that catalyse, not substances".

After the First World War he turned his attention to the reaction complex of the acids and oxides of nitrogen and sulphur, and contributed a number of papers on the mechanism of the reactions in the lead chamber process for the production of sulphuric acid. $\mathrm{He}$ also continued his work on the mechanism of oxidation-reduction reactions and studied the isotope effect in kinetics. During the Second World War he worked on industrial problems of national importance and projected a study of the basic mechanism of the dry cell; he worked on this until his retirement. Even afterwards he did not remain idle: he considered different kinetic mechanisms from a unified point of view in which electron transfer reactions play a central part.

Abel had established a large and vigorous school in Vienna, and his institute produced work on many branches of physical chemistry. He had a peculiar, racy style of lecturing, which was appreciated more by the élite than the average student.

$\mathrm{He}$ took little active part in matters outside science, but had by no means the narrow outlook of the specialist ; those who had the pleasure of hearing his talks to the Austrian Club in London can testify to this. He had an uncomplicated, pleasant nature; though he continued to live in London after the War, he always had a great love for Austria. His eightieth birthday was the occasion for special celebrations by the Academy of Sciences in Vienna and the Bunsengesellschaft.

His two children of his first marriage, and his second wife, survive him.

H. TOMPA

\section{Dr. J. S. Farquharson}

THE meteorological service of Great Britain lost a well-known and senior member of its staff, when Dr. James Strachan Farquharson lost his life in a fatal motoring accident on January 31. Dr. Farquharson was born on June 30, 1904, and joined the Meteorological Office in July 1925 after graduation in the University of Aberdeen. $\mathrm{He}$ served in various divisions of the Meteorological Office, mainly those concerned with meeting the requirements of civil aviation and the Royal Air Force, both at home and overseas. In June 1954, Dr. Farquharson was appointed as assistant director for public services and, in this capacity, did much to develop both the television and weather broadcasts and the automatic telephone weather service in Britain.

The death of Dr. Farquharson was also a sad loss to the Royal Meteorological Society, of which he had been a Fellow since 1934. As honorary treasurer of the Society, he succeeded in introducing a modification of the old-established policy of investing in gilt-edged securities-a change which he firmly believed will prove of considerable value to the Society. His contributions to the Society's Quarterly Journal included two studies related to the development of Empire air routes, namely, "Haboobs and Instability in the Sudan" and "The Diurnal Variation of Wind over Tropical Africa".

The death of Dr. Farquharson has brought to an untimely end an experienced and energetic personality with a wide comprehension of, and original ideas for meeting, the meteorological requirements of the community.

\author{
Mr. F. J. Welch
}

THE death on May 7 of Mr. F. J. Welch, for forty-six years an assistant in the George Holt Physics Laboratory of the University of Liverpool, has severed one of the few remaining links of personal association with Sir Oliver Lodge, Lyon Jones professor of physics in 1900. Mr. Welch was then only in his early twenties, but his recollections of the great man-and his wireless aerial-were very vivid.

Prof. Wilberforce followed Sir Oliver and held the chair for thirty-five years, and Mr. Welch became senior laboratory steward during this period. Those were the days when popular lectures were delivered on "Liquid Air", and also when medical as well as science students attended lectures and demonstrations in physics, which brought them all into intimate contact, not only with the teaching staff, but also with Mr. Welch, who acted as demonstrator. Many physicists, medical men, dentists and school teachers now scattered all over Britain will have happy recollections of the kind and helpful way he always had with them at these classes.

Sir James Chadwick became professor of physics in 1935, and until he retired in 1946, Mr. Welch was in the Department and experienced the period of secrecy which followed the splitting of the atom; and he had close contact with other well-known physicists, such as Prof. J. Rotblat and Prof. O. R. Frisch.

It is interesting to note that his eldest son, E. A. Welch, who received his early training in the George Holt Physics Department, is now senior technician in the Department of Physics, University College of North Wales, Bangor. W. J. Pierce

\section{Mr. G. A. Cook}

Mr. George Alfred Cook died suddenly in Melbourne on January 4. He had enjoyed a comparatively brief retirement from the Commonwealth Scientific and Industrial Research Organization, of which he had been secretary during 1944-52. Before the First World War, Cook was an outstanding student at Ormond College in the University of Melbourne and graduated with first-class honours as master of science and bachelor of mining engineering. During the War he was commissioned in the Second Australian Tunnellers, in which unit he gave distinguished service in France and was awarded the Military Cross.

After the War he spent several years in research work in the mining industry, and in 1922 joined the Institute of Science and Industry as a scientific abstractor. The Institute was replaced by the Council for Scientific and Industrial Research, which in turn was succeeded by the Commonwealth Scientific and Industrial Research Organization, and Cook's service with these bodies was continuous. When he joined the Institute in 1922 there were only two people with scientific training on the staff. When he retired as secretary of the Organization, there was a total staff of more than three thousand, of whom one thousand held professional qualifications. Cook, during his early years with the Organization, took a particular interest in making the results of scientific research available to industry, both as an editor of scientific publications and as a writer of non-technical accounts for the general reader. 